Riccardo Guastini

\title{
A realistic view on law and legal cognition
}

\begin{abstract}
Warning
The contents of this site is subject to the French law on intellectual property and is the exclusive property of the publisher.

The works on this site can be accessed and reproduced on paper or digital media, provided that they are strictly used for personal, scientific or educational purposes excluding any commercial exploitation. Reproduction must necessarily mention the editor, the journal name, the author and the document reference.

Any other reproduction is strictly forbidden without permission of the publisher, except in cases provided by legislation in force in France.
\end{abstract}

\section{revues.org}

Revues.org is a platform for journals in the humanities and social sciences run by the CLEO, Centre for open electronic publishing (CNRS, EHESS, UP, UAPV).

\author{
Electronic reference \\ Riccardo Guastini, «A realistic view on law and legal cognition », Revus [Online], 27 | 2015, Online since 18 August \\ 2015, connection on 24 January 2016. URL : http://revus.revues.org/3304; DOI : 10.4000/revus.3304 \\ Publisher: Klub Revus - Center za raziskovanje evropske ustavnosti in demokracije \\ http://revus.revues.org \\ http://www.revues.org \\ Document available online on: \\ http://revus.revues.org/3304 \\ Document automatically generated on 24 January 2016. The page numbering does not match that of the print edition. \\ All rights reserved
}




\section{Riccardo Guastini}

\section{A realistic view on law and legal cognition}

Pages in print edition : $\mathrm{p}$

Legal realism - or, better, one form of analytical legal realism ${ }^{1}$ - can be characterized as the conjunction of three strictly connected theses: ontological, interpretive, and epistemological. The ontological thesis is about the law itself - it answers the question "What kind of entity (or set of entities) is the law?".

The interpretive thesis, as the name suggests, is about legal interpretation - it answers the question "What kind of activity is interpreting legal texts?". The epistemological thesis is about legal knowledge (or "legal science", as it is usually labelled in continental jurisprudence) - it answers the question "In what does the scientific knowledge of law consist?".

I shall begin by discussing the interpretive thesis since it is logically prior to the others.

\section{Interpretive Realism}

A preliminary distinction is necessary. ${ }^{2}$ In the legal domain, "interpretation" is the name of (at least) two different activities, that is:

(a) "cognitive" interpretation, which amounts to the analysis of a text in view of clarifying its possible (plausible) meanings, ${ }^{3}$ and

(b) "adjudicative" interpretation which consists in ascribing a definite meaning to a text (rejecting the others).

Interpretive realism is a sceptical theory of adjudicative interpretation. It asserts that ascribing meaning to normative texts is a non-cognitive activity - not a matter of cognition, but rather a matter of decision ${ }^{4}$

This holds for judicial interpretation (which is the usual, limited, subject of current theories of interpretation") as well as for "dogmatic" interpretation, that is, the interpretation put forward by legal scholars.

Moreover, a further distinction between interpretation strictly so called and legal construction is in order.

\subsection{Interpretation strictly so called}

Legal texts are affected by a double form of indeterminacy.

On the one hand, normative formulations are often ambiguous. Therefore they admit different competing interpretations "in abstracto" (or text-oriented): the normative sentence $\mathrm{S}$ can be interpreted as expressing either a norm N1 or a norm N2.

On the other hand, each norm is vague, admitting of different competing interpretations "in concreto" (or fact-oriented): given any norm, we may ask whether the individual case C is included or excluded from its scope. ${ }^{6}$

15 This is why interpretive sentences - "in abstracto" ("The normative sentence $\mathrm{S}$ expresses the norm N1") as well as "in concreto" ("The case C falls within the scope of the norm N1") are not cognitive or descriptive, but ascriptive sentences. ${ }^{7}$ Just like stipulative definitions, they are not descriptions of the one and only preexisting meaning, but decisions about competing meanings. ${ }^{8}$ Therefore, they have no truth-value.

By the way, it is a matter of course that interpretive decisions of jurists, lawyers, and judges are conditioned by their practical (for instance, political, economic, professional, etc.) interests and ideas of justice, as well as - last not least - the conceptual constructions of legal dogmatics. Moreover, jurists, lawyers, and judges often are the very source of the indeterminacy of legal texts, in the sense that they "put" indeterminacy in texts that would not raise any interpretive problems at all in ordinary conversation. 


\subsection{Legal construction}

In juristic common parlance the term "interpretation" usually applies to the bulk of the intellectual operations accomplished by interpreters (judges, lawyers, jurists, etc.).

Nevertheless, it is quite easy to realize that interpreters - and above all legal scholars - do not confine themselves to deciding the meanings of normative texts. Most importantly, they engage in what, borrowing an expression from Rudolf von Jhering, I propose to call "legal construction". By this phrase I mean a set of intellectual operations which include (inter alia):

(a) the creation of normative and axiological gaps; ${ }^{9}$

(b) the creation of axiological hierarchies among norms;

(c) the specification of principles;

(d) the balancing of conflicting principles; and

(e) most of all, the construction of unexpressed (so-called "implicit") norms. ${ }^{10}$

Various connections exist among such different operations. For instance, the construction of unexpressed norms is aimed at filling gaps and specifying principles. Axiological hierarchies are aimed at balancing conflicting principles. And so forth.

Now, if interpretation properly understood is not a cognitive activity, legal construction is a fortiori the output not of cognition, but of decision. In fact, legal construction amounts to genuine juristic and/or judicial law-creation. ${ }^{11}$

\section{Ontological Realism}

Legal realism endorses an empiricist ontology of law. Law is not a set of abstract entities (such as norms, values, rights and obligations, or the like). ${ }^{12}$ Rather, it is merely a set of facts. What kind of facts, however? This question requires an articulate answer.

\subsection{Law as a set of normative texts}

At a first glance (at a surface level of analysis) the word "law" simply refers to the normative texts (statutes, codes, constitutions, regulations) enacted by law-giving agencies: such normative authorities as the legislators, the framers of the constitution, and so on. In other words, "law" denotes a set of normative (prescriptive, directive) formulations or sentences, hence facts of a certain kind - namely, language-entities.

Such a concept of law - well reflected in many current expressions, such as "interpreting the law" - although somewhat unsophisticated may be useful in view of clarifying both the basic ontology and the very genesis of legal norms, since:

(a) in the first place, norms are but language-entities; and

(b) in the second place, norms can only come into the world by means of acts of "legislation" (in the generic, material, sense of "legislating") - "No imperative without an imperator, no command without a commander."13

Nonetheless, normative texts obviously require interpretation. Normative formulations must not be confused with norms properly understood, that is, their meaning contents..$^{14}$ If the normative sentence $\mathrm{S}$ can be interpreted as expressing either the norm $\mathrm{N} 1$ or the norm $\mathrm{N} 2$, what is the law? N1 or N2?

Thus we are obliged to say that legal texts are not "the law": after all, they are but sources of law. ${ }^{15}$ Law is not a set of normative sentences, but the set of normative meanings (that is, norms strictly understood) which are actually ascribed to legal texts by interpreters, either by means of interpretation in the strict sense or by means of legal construction. ${ }^{16}$

\subsection{Law as a set of norms}

This is why, at a deeper level of analysis, we have to use the term "law" to denote not normative texts, but rather normative meanings: the set of norms which interpreters actually "extract" or "construe" from normative formulations.

Such a set includes both the class of expressed norms (that is, the norms which are meanings plausibly assignable to the existing normative formulations) and the class of unexpressed norms (that is, the norms construed by interpreters). 
From this standpoint, law depends on the combination of two different activities: (a) the formulation of normative texts, and (b) the interpretation and construction of such texts. There is no law without texts to be interpreted (first ontological thesis), but moreover there is no law without interpretation (second ontological thesis). In a sense, law is a set of interpretive practices.

However, legal scholars and judges - at least diachronically - often disagree: many normative formulations are subject to competing interpretations; the existence (in the legal system) of any unexpressed norm is intrinsically controversial, since such a norm lacks any official formulation. Different interpretations and constructions bring forward different sets of norms, hence (partially) different legal systems.

For example, according to a certain jurisprudential trend, the legal system includes, say, the expressed norms N1, N2, N3, and the unexpressed norms N4 and N5. Whereas, according to a different jurisprudential trend, the same system includes the expressed norms N1, N2 (not N3), and the unexpressed norms N4, N5, but also N6. Thus, we are facing to two distinct legal systems: $\{\mathrm{N} 1, \mathrm{~N} 2, \mathrm{~N} 3, \mathrm{~N} 4, \mathrm{~N} 5\},\{\mathrm{N} 1, \mathrm{~N} 2, \mathrm{~N} 4, \mathrm{~N} 5, \mathrm{~N} 6\}$.

Therefore we should ask: what is the law in such circumstances? Which of these two systems is the law? To answer such a question one must climb down to the deepest level of analysis, corresponding to a third concept of law.

35 Nonetheless, this second concept of law - although still unsatisfactory - has the merit of accounting for the fact that the law is not produced by "legislators" only. In legal practice, side by side with law-giving authorities, one finds interpreters too, and the law in a sense arises from the interaction of legislators and interpreters. One cannot even imagine the law without interpreters (namely, jurists) as well as one cannot imagine a religion without priests or theologians.

\subsection{Law as a set of norms in force}

At the third, deepest, level of analysis, the term "law" refers to the set of norms in force, that is, the norms actually applied (that is, used in deciding cases) in the past and predictably applied in the future by law-applying agencies - judges, administrative agencies, as well as supreme constitutional organs (as far as constitutional norms are concerned). ${ }^{17}$

In other words, notwithstanding the existing different interpretations and constructions, one can (almost) always find a number of synchronically leading interpretations and constructions generally accepted - the "law in action", as we may call it.

Let us go back to the preceding (abstract) example. According to the first jurisprudential trend the content of the legal system is $\{\mathrm{N} 1, \mathrm{~N} 2, \mathrm{~N} 3, \mathrm{~N} 4, \mathrm{~N} 5\}$; according to the second it is $\{\mathrm{N} 1$, $\mathrm{N} 2, \mathrm{~N} 4, \mathrm{~N} 5, \mathrm{~N} 6\}$. To identify what the law is in fact, we have to ascertain which of the norms in question is in force. And it is quite possible that the empirical analysis of the leading jurisprudential trends shows, for example, that N1, N2, N4, N5 as well as N7 are in force, while N3 and N6 are not.

Summing up, by the word "law" one can understand three different things:

(i) the set of the normative texts enacted by the lawgiving authorities;

(ii) the set of (expressed and unexpressed) norms formulated by interpreters;

(iii) the set of (expressed and unexpressed) norms actually in force.

This leads us to the epistemological thesis.

\section{Epistemological Realism}

A preliminary distinction is in order. In the common usage of continental jurisprudence, the ordinary juristic work is frequently labelled as "legal science", "legal doctrine", or "legal dogmatics". But all such phrases can be understood as pointing to (at least) two quite different intellectual enterprises which ought to be distinguished:

(i) on the one hand, legal science properly so called - the "science of jurisprudence" (J. Austin ${ }^{18}$ ), the "science of law" (Kelsen $\left.{ }^{19}\right)$ - that is, the scientific (neutral, value-free) description of the law in force; 
(ii) on the other hand, what I shall call legal scholarship, that is, the usual academic investigation into the law, namely into those normative texts which are regarded as the official sources of law.

For this reason epistemological realism includes two distinct theses - the first one being a descriptive thesis concerning actual legal scholarship, and the second one being a prescriptive thesis bearing upon the scientific knowledge of the law.

\subsection{Legal scholarship}

Given what we have said, the actual practice of jurists cannot be considered as a genuine scientific enterprise, since juristic sentences (or the greater part of them) are neither true nor false, and hence non-cognitive. Interpretive sentences are not descriptive, but ascriptive, and the sentences which formulate unexpressed norms are secretly prescriptive. ${ }^{20}$ Legal scholars do not describe the law - they contribute to making it.

According to a classical view of analytical legal philosophy, legal scholarship is a metalinguistic enterprise that takes the language of the lawgivers as its object-language. ${ }^{21}$ Unfortunately, that picture of legal scholarship is, although seductive, somehow misleading. The language of lawgivers and the language of interpreters are actually subject to a continuous osmotic process. Juristic language does not simply "bear upon" lawgivers' language. Rather, jurists shape and enrich the object of their study, like a violinist interpolating apocryphal notes in the composition he or she is executing. Interpretation and construction are not legal cognition - rather, they are pieces of legal policy ${ }^{22}$ In fact, they are part (an essential part) of the very object of legal cognition properly understood.

Nevertheless, jurists do contribute to the cognition of law, too, in the ways we are going to see.

\subsection{Legal science}

From the standpoint of the form of legal realism outlined in this paper, legal science cannot consist in describing such abstract entities as obligations or rights and/or the deontic properties of behaviour ("It is obligatory that $p$ ", "It is prohibited that q"), and the like. And, as a consequence, its sentences cannot be deontic sentences repeating - iterating, like an echo ${ }^{23}-$ the norms they refer to. ${ }^{24}$

Legal science properly understood can assume three different forms, corresponding to the three concepts of law developed in the previous section.

51 (i) Cognitive interpretation. Talking about interpretation, I dealt with "adjudicative" interpretation - the ascription of a definite meaning to a given legal text. And adjudicative interpretation is the usual and most important job of legal scholars. Nonetheless, they also accomplish a different task, namely, "cognitive" interpretation which consists in identifying the various possible meanings of a normative text - the meanings admissible on the basis of shared linguistic (syntactic, semantic, and pragmatic) rules, accepted methods of legal interpretation, and existing juristic theories - without choosing anyone of them ("The text T can be interpreted in the senses S1 or S2").

52 Cognitive interpretation contributes to the knowledge of law understood as a set of normative texts, since it reveals the ambiguity of normative formulations and the vagueness of norms. ${ }^{25}$ (ii) Reconstruction of jurisprudential trends. Understanding the law (not as a set of normative formulations, but) as a set of expressed and unexpressed norms, the analysis, reconstruction, and description of the interpretive and constructive trends of judges and jurists constitute obvious contributions to the knowledge of law.

54 And this, too, is a common practice among legal scholars, which contributes to legal knowledge, since it is a necessary preliminary to ascertaining the prevailing jurisprudential trends, which, in turn, is a necessary preliminary to identifying the law in force.

55 (iii) Description of the law in force. Understanding the law as a set of norms in force, the cognition and description of the law requires the identification of the norms actually applied by judges and other law-applying agencies. ${ }^{26}$ (No need to say that, where no definite norm regarding a certain matter is in force, legal science can only take note of the existing jurisprudential conflicts.) 
One may agree with the prevailing view according to which legal science consists in a set of "normative propositions", that is, true or false sentences concerning norms ${ }^{27}$ However, two clarifications are in order: the first one pertains to the logical form of normative propositions, and the second to their conditions of truth.

(a) As I already said, normative propositions are not deontic sentences about the normative qualification of behaviour. ${ }^{28}$ Rather, they are existential sentences about norms (in force). The "legal" existence of a norm is simply its membership in a definite legal system. Hence, normative propositions, whatever their actual syntactic form may be, are sentences which state the membership of norms (in force) within a definite legal system: "The norm $\mathrm{N}$ belongs to the legal system $S^{\prime \prime}$.

(b) A normative proposition is true if, and only if, the norm which it refers to will be predictably applied in future decisions. Therefore, normative propositions can be understood as propositions on contingent futures: predictions concerning the future application of the norms they refer to.

\section{Bibliography}

John AUSTIN, 1995: The Province of Jurisprudence Determined (1832). Ed. W.E. Rumble. Cambridge: Cambridge U.P.

John L. AUSTIN, 1962: How to Do Things with Words. Oxford: Clarendon Press.

Norberto BOBBIO, 2011: Scienza del diritto e analisi del linguaggio (1950), in Norberto Bobbio, Saggi sulla scienza giuridica. Torino: Giappichelli.

Eugenio BULYGIN, 1982: Norms, Normative Propositions and Legal Statements, in Contemporary Philosophy. A New Survey. Vol. 3. Ed. G. Fløistad. Dordrecht: Kluwer.

— 1991: El concepto de vigencia en Alf Ross (1963), in C.E. Alchourrón \& E. Bulygin, Análisis lógico y derecho. Madrid: Centro de Estudios Constitucionales.

John C. GRAY, 1948: The Nature and Sources of the Law. 2nd edition from the author's notes. New York: Columbia U.P.

Riccardo GUASTINI, 1997: Interpretive Statements, in Normative Systems in Legal and Moral Theory. Festschrift for Carlos E. Alchourrón and Eugenio Bulygin. Eds. E. Garzón Valdés et al. Berlin: Duncker \& Humblot.

_ 2000: Sollsätze. An Exercise in Hard Legal Positivism, Rechtstheorie 31 (2000) 2.

- 2011a: Interpretare e argomentare. Milano: Giuffré.

2011b: Rule-Scepticism Restated, in Oxford Studies in Philosophy of Law. Vol. 1. Eds. L. Green

\& B. Leiter. Oxford: Oxford U.P.

2013: Juristenrecht. Inventing Rights, Obligations, and Powers, in Neutrality and Theory of Law.

Eds. J. Ferrer Beltrán et al. Dordrecht: Springer.

Hans KELSEN, 1950: The Law of the United Nations. A Critical Analysis of Its Fundamental Problems. London: Stevens \& Sons.

_ 1967: Pure theory of Law (1960). Trans. M. Knight. Berkeley: University of California Press. 1973: Law and Logic (1965), in Essays in Legal and Moral Philosophy. Ed. O. Weinberger. Trans.

P. Heath. Dordrecht: Reidel.

— 1991: General Theory of Norms (1979). Trans. M. Hartney. Oxford: Clarendon.

_ 1992: Introduction to the Problems of Legal Theory (1934). Trans. B. Litschewski Paulson \& S.L. Paulson. Oxford: Clarendon.

Karl OLIVECRONA, 1971: Law as Fact. 2nd ed. London: Stevens \& Sons.

Alf ROSS, 1957: Tû-Tû, Harvard Law Review 70 (1957) 5.

— 1958a: On Law and Justice (1953). London: Stevens \& Sons.

_ 1958b: Definition in Legal Language, Logique et analyse (1958) 3-4.

Uberto SCARPELLI, 1967: Le 'proposizioni giuridiche' come precetti reiterati, Rivista internazionale di filosofia del diritto (1967) 44.

Giovanni TARELLO, 1974: Diritto, enunciati, usi. Studi di teoria e metateoria del diritto. Bologna: Il Mulino.

— 1980: L'interpretazione della legge. Milano: Giuffré. 


\section{Notes}

1 The form of legal realism I am going to sketch shares some tenets with other forms of realism (the American and the Scandinavian, in particular), but does not coincide with any of them.

2 The following distinction echoes Kelsen's distinction between interpretation understood as (a) an act of cognition and (b) an act of will, respectively. See Kelsen 1992: 82 f. and Kelsen 1950: Preface.

3 A "plausible" meaning is a meaning that can be maintained with persuasive arguments and, as a matter of sociological fact, can be accepted within a given legal culture.

4 Guastini 2011b. This view is indebted to Tarello's theory of interpretation. See Tarello 1974 and 1980.

5 Kelsen's and Tarello's theories are two remarkable exceptions.

6 There should be no need to say that further (and maybe even more important) forms of indeterminacy depend on legal gaps and normative conflicts. Gaps and conflicts, however, do not forerun interpretation - they follow it. In most cases legal texts disclose gaps and/or conflicts in the light of certain interpretations, while a different interpretation might make the gaps and/or the conflicts disappear.

7 I refer to those interpretive sentences that do not simply report or take notice of the indeterminacy of a given legal text ("The legal text T may be understood in the senses S1 or S2"), but resolve it ("The legal text T definitely means S1"). Such sentences resemble J.L. Austin's performatives, that do not "describe" or "report" or constate anything at all, are not "true or false" (J.L. Austin 1962: 5) - they perform the linguistic act of meaning-ascription, i.e., interpretation.

8 Guastini 1997.

9 All gaps, in a sense, are "created" by interpreters since the identification of a gap presupposes interpretation: e.g., according to interpretation A the case at hand is regulated by some legal provision, while according to interpretation B the same case is not. So, interpretation B "creates" a gap, while interpretation A prevents it. By the way, axiological gaps, in particular, entirely depend on interpreters' value-judgments.

10 All such concepts are fully analyzed in Guastini 2011a. But a short characterization runs as follows: (a) a normative gap is the lack of any legal regulation of a case; (b) an axiological gap is the lack of a satisfactory regulation (and the presence of an unsatisfactory one); (c) an axiological hierarchy between two norms is a value-relationship created by interpreters by means of a comparative value-judgement; (d) specifying a principle amounts to deriving from it an unexpressed rule; (e) balancing conflicting principles consists in establishing an axiological hierarchy between them; (f) an unexpressed norm is a norm which lacks any official formulation in the sources of law, not being a plausible meaning of any particular normative sentence.

11 See Guastini 2013.

12 By the way, according to a distinctive realistic thesis, deontic concepts (such as obligation, prohibition, etc.) as well as so-called "fundamental legal concepts" (such as right, power, etc.) are deprived of any semantic reference. See, e.g., Ross (1957 and 1958b) and Olivecrona (1971).

13 See Kelsen 1973, 237, and 1991: 3 (echoing a thesis of Walter Dubislav).

14 This is the reason why interpretive realism is logically prior to ontological realism.

15 See Gray (1948: 124 s and 170): After all, it is only words that the legislature utters; it is for the courts to say what these words mean; that is it is for them to interpret legislative acts. [...] And this is the reason why legislative acts, statutes, are to be dealt with as sources of Law, and not as a part of the Law itself. [...] The courts put life into the dead words of the statute»; «It may be urged that if the Law of a society be the body of rules applied by its courts, then statutes should be considered as being part of the Law itself, and not merely as being a source of the Law; that they are rules to be applied by the courts directly, and should not be regarded as fountains from which the courts derive their own rules. [...] And if statutes interpreted themselves, this would be true; but statutes do not interpret themselves; their meaning is declared by the courts, and it is with the meaning declared by the courts, and with no other meaning, that they are imposed upon the community as Law.

16 As to the ontology of meanings, I shall confine myself to say that the meaning of a sentence is nothing but another sentence assumed to be synonymous with the first one. From this point of view, meanings too are linguistic entities.

17 The obvious reference is to Ross 1958a. See however Bulygin 1991.

18 J. Austin 1995: 14, $112 \mathrm{s.}$

19 Kelsen 1992: 7 and 1966: ch. III.

20 "Secretly", since such sentences usually claim to be existential propositions about norms - "The unexpressed norm $\mathrm{N}$ belongs to (exists in) the legal system $\mathrm{S}$ " - although they are genuine normative formulations, i.e., formulations of brand "new" norms.

21 Bobbio 2011. 
22 See Kelsen 1992: 82; Ross 1958: 46.

23 Scarpelli 1967.

24 Contrary to Kelsen's view. See e.g. Bulygin 1982.

25 By the way, cognitive interpretive sentences can be understood: either as predictions of future interpretive decisions of law-applying agencies; or as interpretive directives aiming at guiding such future decisions, namely, by circumscribing the range of admissible meanings of the text concerned.

26 See once more Ross 1958a: ch. 2 and Bulygin 1991.

27 See, e.g., Bulygin 1982.

28 Guastini 2000.

\section{References}

Electronic reference

Riccardo Guastini, «A realistic view on law and legal cognition », Revus [Online], 27 | 2015, Online since 18 August 2015, connection on 24 January 2016. URL : http://revus.revues.org/3304 ; DOI : $10.4000 /$ revus. 3304

Bibliographical reference

Riccardo Guastini, «A realistic view on law and legal cognition », Revus, 27 | 2015,

\section{Author}

\section{Riccardo Guastini}

Professor in Legal Philosophy, Tarello Institute for Legal Philosophy, Department of Law, University of Genoa

Riccardo Guastini

Tarello Institute for Legal Philosophy

Via Balbi 30/18

16126 Genoa

Italy

E-mail: guastini@unige.it

\section{Copyright}

All rights reserved

\section{Abstract}

The author outlines one form of analytical legal realism as the junction of three main theses. According to its first main thesis, interpretive sentences in legal discourse are ascriptive sentences with no cognitive function. According to the second thesis, the law is the set of norms in force, i.e. the norms actually applied (that is, used in deciding cases) in the past and predictably applied in the future by law-applying agencies. The third thesis is that legal science as a cognitive activity must not be confused with legal scholarship. Although legal scholars do engage in cognitive activities, their work mainly consists in non-cognitive activities such as interpretation and legal construction. I An earlier version of this statement was published in Revus (2013) 19 in Italian, French, and Croatian.

\section{Index terms}

Keywords : legal realism, interpretive scepticism, ontology of law, legal scholarship, legal science 